\title{
Evaluation of Garlic Variety for Better Growth and Higher Yield under Allahabad Agro - Climatic Condition
}

\author{
Omnarayan Verma ${ }^{1 *}$ and Bhupendra Thakre ${ }^{2}$
}

${ }^{1}$ Department of Horticulture, College of Agriculture, Allahabad Agricultural InstituteDeemed University, Allahabad, UP, India

${ }^{2}$ Plant Pathology, Zonal Agricultural Research Station, JNKVV, Chhindwara, MP, India

*Corresponding author

\begin{tabular}{|l|}
\hline Ke y w o r d s \\
$\begin{array}{l}\text { Garlic, Allium } \\
\text { sativum L., Growth, } \\
\text { Yield, Quality, } \\
\text { Varietal evaluation }\end{array}$ \\
\hline Article Info \\
\hline $\begin{array}{l}\text { Accepted: } \\
\text { 20 January } 2018 \\
\text { Available Online: } \\
\text { 10 February } 2018\end{array}$ \\
\hline
\end{tabular}

\section{Introduction}

Garlic (Allium sativum L.) is an important spice crop only to onion (Allium cepa L.). It belongs to the family; Alliaceae with genus Allium and species sativum having $2 \mathrm{n}=16$ chromosome number. The native place is central Asia and Southern Europe, specially the Mediterranean region. This crop is grown as an important spice and condiment, through it is treated as a maligned vegetable in India, due to its undesired flavor, it is grown for medicinal usage in pharmaceutical industry also. The garlic plants are bulbous, hardy and perennial. The bulb is composed of separable parts of bulbils called "cloves" which range from 6 to 50 and are enclosed by thin sheathe, light pink to white in color. Alliums are 
mostly popular for their flavor which characteristics of sulphur containing compounds formed directing by crashing, following a chemical reaction. Allinase an enzyme present in most numbers of Allium genus is responsible for flavor (Nutrition vol. 29, No. 1). Garlic has higher nutritive value than other bulb crops. A fresh peeled garlic clove $100 \mathrm{~g}$ contains moisture $62.8 \%$, Protein $6.3 \mathrm{~g}$, Fat $0.1 \mathrm{~g}$, mineral $1 \mathrm{~g}$, Fiber $0.8 \mathrm{~g}$, Carbohydrate 29\%, calcium $0.03 \mathrm{~g}$, Phosphorus $310 \mathrm{mg}$, Iron $10 \mathrm{mg}$, calories $145 / 100 \mathrm{~g}$., Nicotinic acid $0.40 \mathrm{mg} / 100 \mathrm{~g}$ and vitamin-C $13.0 \mathrm{mg} / 100 \mathrm{~g}$. Garlic is grown throughout the plains of India. Generally it's grown as a winter crop in Madhya Pradesh, Gujarat, Rajasthan, Maharashtra and Uttar Pradesh. In India garlic is cultivated in 134.9 thousand hectare of land, Producing 598.2 thousand tones with an average yield of 4.43 tons per hectare (The Hindu Survey of Indian Agriculture 2007).

\section{Materials and Methods}

The experimental area was ploughed with mould board plough and harrowing was done to bring soil to a fine tilt. Well decomposed farmyard manure @ 20.0 tonnes per hectare was applied and mixed well in the soil before final harrowing. The experimental site was divided in to a required number of plots of $1.25 \mathrm{~m} \times 1 \mathrm{~m}$ size. The main and sub-irrigation channels were laid out, taking into consideration of gradient of the site. After layout of plots, the treatments were arranged to the different plots in each replication by using random. The seeds were sown at a spacing of $20 \mathrm{~cm} \times 10 \mathrm{~cm}$. Cloves were detached carefully from the composite bulbs and used for planting. Only sound; bold unbroken and uninjured cloves were selected and used. The time of sowing is from $15^{\text {th }}$ October to $15^{\text {th }}$ November. Observation was recorded Two type one is Pre-harvest observation germination \%, Plant height $(\mathrm{cm})$
Neck girth (cm), and Second is Pre-harvest observation Fresh weight of bulbs (g), yield per pot (Kg), Bulb yield (t / Ha). Randomized Block Design was adopted for conducting the experiment. The data recorded during the course of the study were subjected to statistical analysis as per method of (Analysis of variance) suggested by Fisher (1958).

\section{Results and Discussion}

\section{Germination percentage}

The data on germination percentage as influenced by different varieties are presented in Table 1 and graphically depicted in Figure 1. The germination percentage was influenced by different varieties and the results were found to be significant. The maximum germination percentage was recorded in $\mathrm{KS}-2$ (97.33) followed by G-4 (96.67\%), Local (96.33\%), IC-35265 (96.00\%), G-283 $(95.33 \%)$ and Kaveri $(94.33 \%)$. The minimum germination percentage was recorded in agri found white $(93.33 \%)$ ). The higher germination percentage in KS-2 may be due to viability. The seed viability varies with the species and storage conditions reported by Baten et al., (1989) and Pandey and Sinha (1996).

\section{Plant height (cm)}

The plant height was influenced by different varieties at $25 \mathrm{DAP}$ and result were found to be significant. The plant height was the highest in KS-2 $(25.87 \mathrm{~cm})$, followed by G-4 $(24.68 \mathrm{~cm})$, Local $(23.93 \mathrm{~cm}), \quad$ IC-35265 $(23.83 \mathrm{~cm}), \mathrm{G}-283(23.47 \mathrm{~cm})$ and Kaveri $(22.93 \mathrm{~cm})$ respectively. The minimum plant height was recorded in agrifound white (19.60 $\mathrm{cm})$. At 50 days after planting and result were found to be significant. The plant height was the highest in Ks-2 $(31.53 \mathrm{~cm})$ followed by G$4(31.43 \mathrm{~cm})$, Local $(30.77 \mathrm{~cm})$, Ic-35265 $(30.40 \mathrm{~cm}), \mathrm{G}-283(29.60 \mathrm{~cm})$ and Kaveri $(28.80 \mathrm{~cm})$ respectively. 
Table.1 Performance of different verities of garlic (Allium Sativam L.)

\begin{tabular}{|c|c|c|c|c|c|c|c|c|c|}
\hline \multirow[b]{2}{*}{ Varieties } & \multirow[t]{2}{*}{ Germination $\%$} & \multicolumn{3}{|c|}{ Plant Height $(\mathrm{cm})$} & \multicolumn{3}{|c|}{ Neck Girth (cm) } & \multirow{2}{*}{$\begin{array}{c}\text { Fresh } \\
\text { Weight of } \\
\text { bulb (gm) }\end{array}$} & \multirow{2}{*}{$\begin{array}{l}\text { Bulb Yield } \\
\text { per Plot } \\
\text { (kg) }\end{array}$} \\
\hline & & 25 DAS & 75 DAS & 125 DAS & 25 DAS & 75 DAS & 125 DAS & & \\
\hline Local & 96.33 & 23.93 & 53.17 & 65.33 & 0.41 & 1.20 & 1.25 & 33.58 & 2.08 \\
\hline Agrifound White & 93.33 & 19.60 & 48.10 & 59.07 & 0.33 & 1.11 & 1.17 & 25.85 & 1.60 \\
\hline IC-35265 & 96.00 & 28.83 & 52.57 & 64.80 & 0.39 & 1.19 & 1.24 & 32.10 & 1.99 \\
\hline G-283 & 95.33 & 23.47 & 52.17 & 62.53 & 0.38 & 1.18 & 1.23 & 31.91 & 1.98 \\
\hline Kaveri & 94.33 & 22.93 & 50.80 & 62.27 & 0.36 & 1.11 & 1.20 & 28.37 & 1.76 \\
\hline KS-2 & 97.33 & 25.87 & 54.53 & 67.00 & 0.42 & 1.23 & 1.29 & 40.49 & 2.51 \\
\hline $\mathrm{G}-4$ & 96.67 & 24.67 & 54.47 & 65.93 & 0.41 & 1.21 & 1.27 & 36.51 & 2.26 \\
\hline SEm \pm & 0.39 & 0.15 & 0.16 & 0.14 & - & & & 0.31 & 0.02 \\
\hline C.D $(p=0.05)$ & 0.85 & & & & & & & 0.67 & 0.04 \\
\hline
\end{tabular}

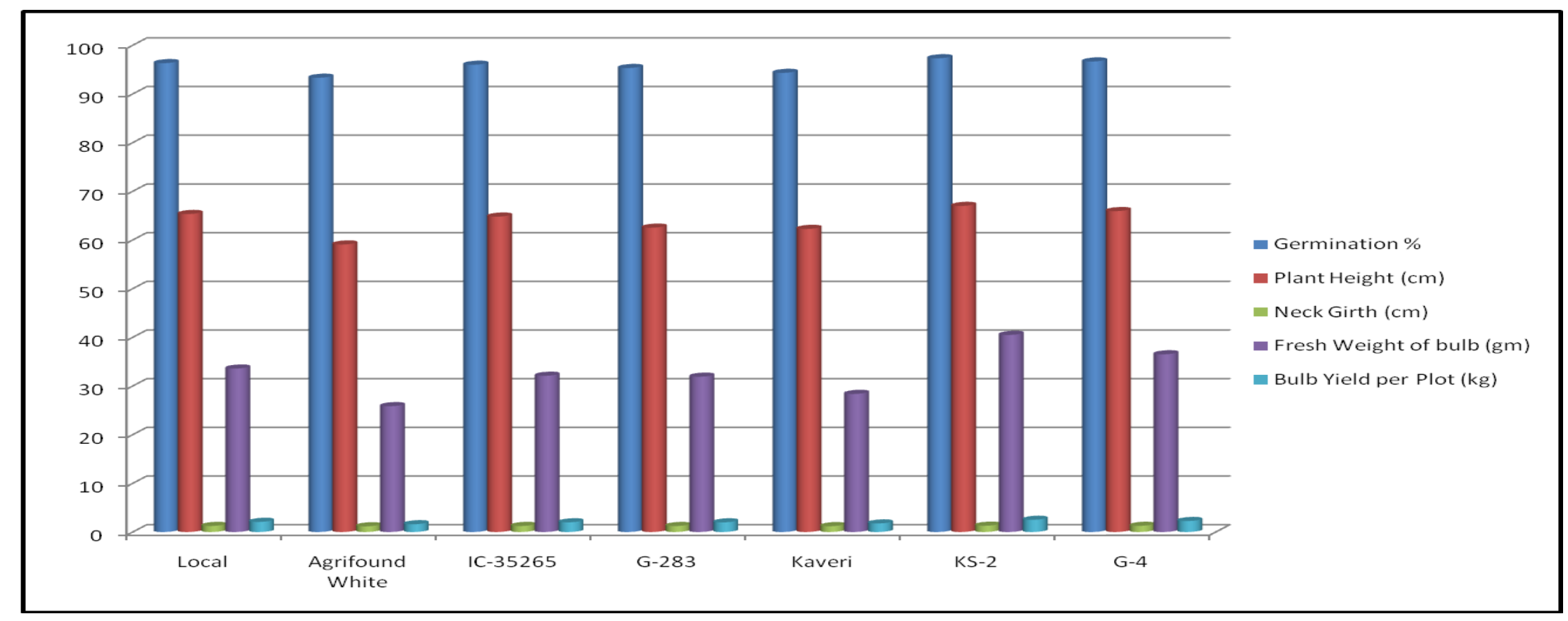


The minimum plant height recorded in agrifound white $(27.57 \mathrm{~cm})$, At 75 days after planting and result were found to be significant. The plant height was the highest in KS-2 $(54.53 \mathrm{~cm})$, followed by G-4 $(54.47$ $\mathrm{cm})$, Local $(53.17 \mathrm{~cm})$, IC-35265 $(52.57 \mathrm{~cm})$, G-283 (52.17 cm) and Kaveri $(50.80 \mathrm{~cm})$ respectively. The minimum plant height was recorded in agrifound white $(48.10 \mathrm{~cm})$, At 100 days after planting and result were found to be significant. The maximum plant height was recorded in $\mathrm{KS}-2(69.67 \mathrm{~cm})$, followed by G-4 $(69.00 \mathrm{~cm})$, local $(67.83 \mathrm{~cm})$, IC$35265(67.27 \mathrm{~cm}), \mathrm{G}-283(65.57 \mathrm{~cm})$ and Kaveri $(64.67 \mathrm{~cm})$ respectively. The minimum plant height was recorded in agrifound white $(62.30 \mathrm{~cm})$ and at 125 days after planting and result was found to be significant. The maximum plant height was recorded in KS-2 $(67.00 \mathrm{~cm})$, followed by G$4(65.93 \mathrm{~cm})$, Local $(65.33 \mathrm{~cm})$, IC-35265 $(64.80 \mathrm{~cm}), \mathrm{G}-283(62.53 \mathrm{~cm})$ and Kaveri $(62.27 \mathrm{~cm})$. The minimum plant height was recorded in agrifound white $(59.07 \mathrm{~cm})$, respectively. Similar result were also reported by Noor et al., (1999) and Singh and Tiwari (1994).

\section{Neck girth (cm)}

The neck girth was not influenced by different varieties at 25 days after planting and results were found to be non-significant. The maximum neck girth was recorded in KS-2 $(0.42 \mathrm{~cm})$, followed by $\mathrm{G}-4(0.41 \mathrm{~cm})$, Local $(0.41 \mathrm{~cm}), \mathrm{IC}-35265$ (0.39), G-283 (0.38) and Kaveri (0.36) respectively. The minimum was recorded in agrifound white $(0.33 \mathrm{~cm}), 50$ days after planting and results were found to be significant. The maximum neck girth was recorded in KS-2 $(0.66 \mathrm{~cm})$, followed by G-4 (0.65), Local (0.65), IC-35265 (0.63), G-283 $(0.63 \mathrm{~cm})$ and Kaveri $(0.62)$ respectively. The minimum was recorded in agrifound white $(0.59 \mathrm{~cm})$, at 75 days after planting and result were found to be significant. The maximum neck girth was recorded in KS-2 $(1.23 \mathrm{~cm})$, followed by G-4 $(1.21 \mathrm{~cm})$, local $(1.20 \mathrm{~cm})$ and Kaveri $(1.11 \mathrm{~cm})$ respectively. The minimum neck girth was recorded in agrifound white $(1.11 \mathrm{~cm})$ at 100 days after planting and results were to be significant. The maximum neck girth was recorded in $\mathrm{KS}$ $2(1.41 \mathrm{~cm})$, followed by G-4 $(1.39 \mathrm{~cm})$, Local $(1.37 \mathrm{~cm})$, IC - $35265(1.36 \mathrm{~cm})$, G$283(1.35 \mathrm{~cm})$ and Kaveri $(1.29 \mathrm{~cm})$ minimum with agrifound white $(1.26 \mathrm{~cm})$.at 125 days after planting and results were found to be significant. The maximum neck girth was recorded in KS-2 $(1.29 \mathrm{~cm})$, followed by G-4 $(1.27 \mathrm{~cm})$, local $(1.25 \mathrm{~cm})$, IC-35265 (1.24 $\mathrm{cm}), \mathrm{G}-283(1.23 \mathrm{~cm})$ and Kaveri $(1.20 \mathrm{~cm})$ minimum with the agrifound white $(1.17 \mathrm{~cm})$ respectively. Similar result were also reported by Om and Srivastava (1977) and Mettananda and Fordham (1999).

\section{Fresh weight of bulb (g)}

The fresh weight of bulbs was influenced by different varieties and the results were found to be significant. The maximum bulb weight was recorded in $\mathrm{KS}-2$ (40.49 gm), followed by G-4 (36.5 gm), Local (33.58 gm), IC-3565 (32.10 gm), G-283 (31.91 gm) and Kaveri (28.37 gm). The minimum bulb weight was recorded in agrifound white (25.85). KS-2 seemed to be better in position in utilizing the input and in enhancing bulb weight, compared to other varieties in this agro-climatic condition. Similar results were also reported by Korla and Rastogi (1979).

\section{Yield per plot (kg)}

The yield per plot was influenced by different varieties and the results were found to be significant. The maximum yield was with $\mathrm{KS}$ $2(2.51 \mathrm{~kg})$ followed by G-4 $(2.26 \mathrm{~kg})$, Local $(2.08 \mathrm{~kg}), \mathrm{IC}-35265(1.99 \mathrm{~kg}) \mathrm{G}-283$ (1.98 $\mathrm{kg})$, Kaveri $(1.76 \mathrm{~kg})$ and minimum with the agri found white $(1.60 \mathrm{~kg})$ respectively, KS-2 
being prolific vegetative growth variety, must have utilized its leaf capacity, the photosynthesis, which in turn must have helped this variety to be superior than others. Similar results were also reported by Korla and Rastogi (1979) and Pandey et al., (1992).

\section{Bulb yield (t/ha)}

The bulb yield was influenced by different varieties and the results were found to be significant. The maximum yield was with $\mathrm{KS}$ 2 (20.8 t/ha), followed by G-4 (18.11 t/ha), Local (16.66 t/ha), IC-35265 (15.92 t/ha), G283 (15.83 t/ha) and Kaveri (14.07 t/ha). The minimum yield was with agrifound white (12.80 t/ha) similar results were also recorded by Deshmukh and Deore (1990) and Lallen Singh et al., (1993) and Shrestha et al., (2000).

\section{References}

Ayala, A. and Svon, J.R. (1986). Comparative study of garlic (Allium sativum) clones. Agriculture, Hortalizas Ppa, Granosy Fibras. 5(2): 73-80.

Basallote, M.J., Bejarano, J., Blance, M.A., Jimenez Diaz, R.M. and Mebra, J.M. (1994). Soil solarization a strategy for the control of diseases caused by soil borne plant pathogens and for reducing crop rotations. Investigation Agraria, Producciony Vegetables, Fuera deserie No. 2. 207-220.

Baten, M.A., Khan, M.A.H., Karim, M.A. and Mondal, M.F. (1989). Studies on the comparative morphology, yield components and yield of 2 garlic cultivars. Bangladesh Hort. 17(2):3841.

Charchar, J.M., Tenente, R.C.V. and Aragao, F.A.S. (2003). Resistance of garlic cultivars to Ditylenchus dipasaci. Nematologia-Brasileria. 27 (2): 179184.
Deshmukh, V.V. and Deore, B.P. (1990). Relationship between dry matter and yield in garlic genotype. Ann. Of plant physio. 4(1): 122-123.

Gupta, N.K. and Ganeshe, R.K. (2000). Response of Borax and Zinc sulphate on growth and yield of garlic (Allium sativum L.) Advances in Plant Sciences, 13 (1): 237-239.

Humayun-Khan, Azim-Khan, Derawadan, Mazulla-Khan and Abdoul-Mjeed (1997). Environmental effect on garlic genotypes for yield and yield component in Swat Valley. Sarhad J. of Agri., 13 (4): 357-361.

Khar, A., Asha, Devi, Mahajan, V. and Lawande, K.E. (2004). Performance studies of some promising garlic accessions under Rajgurrunagar conditions. J. of Maharashtra Agri. Univ., 29 (2): 214-216.

Lalan-Singh, Dubey, P.K., Pandey, V.B. and Singh, L. (1993). Studies on the performance of defferent promising garlic collection under Nasik conditions in Maharashtra. Newsletter Associated Agricultural Development Foundation. 13 (2): 8-10.

Mangal, J.L. Singh, R.K., Yadav, A.C., Lal, S. and Pandey, U.C. (1990). Evaluation of garlic cultivars for salinity tolerance. J. of Hort. Sci.65 (6): 657-658.

Muller, S. and Biasi, J. (1989). Performance of garlic cultivars on the Santa Catarina Plateau. Horticultura Brasileria. 7 (1): 7-9.

Noor-B., Khalid-M., Badshah, N. and Umar, K. (1999). Evaluation of garlic (Allium sativam L.) cultivars grown under the agro climatic conditions Peshawar valley. 15 (5): 431-436.

Pandey, U.C., Jintender-Singh and Singh, J. (1989). Performance of new varieties of garlic (Allium sativum L.) under varying nitrogen levels. Indian J. of Agro. 41 (1): 174-176. 
Patel, B.G., Khanpara, V.D., Malavia, D.D. and Kneria, B.B. (1996). Performance of drip and surface method or irrigation for garlic (Allium sativum L.) under varying nitrogen levels. Indian $J$. of Agro.41 (1): 174-176.

Rakesh Mehra and Vinod batra (2005). Evaluation of garlic varieties against purple blotch disease and yield. $J$. of Medicinal and Aromatic plant Sci. 27 (1): 7-9.

Sherestha, R.L., Karki, T. and Pun, A. (2000). Performance evaluation on garlic genotypes in the research command area of lumle, during 1998-1999. Working paper, Lumle Agricultural Rrsearch Centre. No. 2000-2001, iii $+5 \mathrm{pp}$.
Singh, D.K., Gupta, R.P., and Choudhary, S.N. (2002). Studies on the evaluation of the performance of advance lines in garlic. News Letter National Hort. Res. And Development foundation. 22 (2): 11-15.

Suberi, H. and Price, T.V. (2000). Stemphylium leaf blight of garlic (Allium sativum L.) in Australia. Australasian plant patho. 29 (3): 192199.

Tiwari, R.S., Ankur Agrawal, Sengar, S.C. and Agrawal, A. (2003). Performance of garlic genotypes under Tarai Region of Uttaranchal. Progress. Hort., 34(2): $183-186$.

\section{How to cite this article:}

Omnarayan Verma and Bhupendra Thakre. 2018. Evaluation of Garlic Variety for Better Growth and Higher Yield under Allahabad Agro - Climatic Condition. Int.J.Curr.Microbiol.App.Sci. 7(02): 2275-2280. doi: https://doi.org/10.20546/ijcmas.2018.702.274 